undertaken. The results of the evaluations conducted by the agency are submitted to the national committee before their circulation.

\section{Conclusions}

Quality assurance as such is mainly a question of attitudes and behaviour. It is difficult to induce doctors to modify their behaviour by pressures other than from inside the profession. In France there are three types of understanding of medical evaluation: that of the official bodies and evaluation units of hospitals, who try to define and disseminate actual quality assurance; that of doctors, who often confuse it with clinical research; and that of government, whose main problem is financial. The fact that, except in the Netherlands, quality assurance has always been promoted by governments or health administrations, or both, and never by the medical profession itself constitutes in the eyes of doctors an original sin that is difficult to overcome. It could also turn against quality assurance itself when governments eventually find out that quantity and quality belong to two different logics and that quality assurance does not necessarily entail savings.

Therefore many problems remain before quality assurance can be integrated routinely in medical practice. Clarification is needed about the concept of quality assurance and the activities actually covered by quality assurance. Clarification is also needed about the government's intentions and its role in developing and managing quality assurance. Ideally, quality assurance should be adopted by the medical profession as an activity of its own, independent of any public or administrative policy. This is not yet the case in France, but things may be stirring.

I thank Dr L René, president of the National Order of Physicians and of the National Committee for Medical Evaluation, and Professor Y Matillon, head of the National Agency for Medical Evaluation, for their informative interviews, and Professor D Jolly and J L Portos for their constructive criticism of a first draft of this article. The opinions expressed are exclusively those of the author.

1 Jolly D, Brodin M, Stephan JC. Les Audits hospitaliers. L'hôpital à Paris 1982;68:102-4.

2 Blum-Boisgard C, Grosgogeat Y, Jolly D. Le CEDIT: 6 ans d'expérience. L'hôpital à Paris 1988;106.

3 Giraud A, Jolly D. How to induce physicians to engage in quality assurance activities in a university hospital: a policy. Quality Assurance in Health Care (in press).

4 Fetter RB, Thompson SD, Averill RF. Development, testing, and evaluation of a prospectivecase-paymentrembursement system. Final report. Yale, Connecticut: Health Systems Management Group, School of Organization and

5 Jolly D. Plaidoyer pour l'évaluation médicale. Le Monde 1991 Apr 3:18.

6 Giraud A, Jolly D. Le consensus en médecine. Méthodes et bilan des conférences de consensus dans le monde. Paris: Editions AP-Doin, 1991.

7 Agence Nationale pour le Développement de l'Evaluation Médicale. Les conférences de consensus. Bases méthodologiques pour leur réalisation en France. Paris: Agence Nationale pour le Développement de l'Evaluation Médicale, 1990

8 Le Gall JR, Loirat P, eds. Evaluation en réanimation. Paris: Masson, 1990.

9 Eddy D. The challenge. FAMA 1990;263:287-90.

10 Armogathe JF. Pour le développement de l'evaluation médicale. Paris: La Documentation Française, 1989.

\title{
Medical audit in France: from ideal to reality
}

\author{
Michel Amouretti, Claude Beraud, Elisabeth Saint-Martin
}

Gastroenterology Unit and Laboratory of Quality Assurance in Medical Care, University of Bordeaux II, 33076 Bordeaux Cedex, France

Michel Amouretti, MD, professor of

hepatogastroenterology

Elisabeth Saint-Martin,

$\mathrm{MD}$, clinical assistant

\section{Caisse Nationale \\ d'Assurance Maladie des \\ Travailleurs Salariés, \\ France \\ Claude Beraud, MD, member of council}

Correspondence to:

Dr Amouretti.

BMf 1992;304:428-30
The increasing difficulties experienced by the health service in France are causing doctors, researchers, and the politicians and administrative policy makers to put forward medical evaluation as one of the main remedies for the problems. And yet the evaluation of health care in France is rather more a hope and expectation than a reality. It is true that scientific work, particularly regarding the new technologies and public health, has been performed in France in the past 10 years; but this has been only sporadic action rather than the development of a true health care policy as conceived of in the United States and Great Britain. Moreover, there is still much conceptual confusion regarding evaluation. Bandied about daily in the press and picked up by all the health organisations and professional bodies, the term "health care evaluation" is associated by some with control strategies having an economic finality whereas for others its importance is more professional or ethical, or both. The imprecise use of the term mirrors the multiple difficulties and barriers that the concept generates within the health profession in France. Its courses are many ${ }^{1}$ : scientific, psychological, sociological, and cultural.

The time now seems right, however, for health care evaluation to develop in France, owing to the realisation of such a need by most health professionals and political and administrative health care policy makers.

Medical audit, as defined in 1989 by the NHS in Great Britain, ${ }^{2}$ covers what is beginning to be known in France as "medical evaluation of health care." The aim is to perform a systematic critical analysis of medical care, including the procedures used for diagnosis and treatment, the use of resources, and the resulting outcome and quality of life for the patient. In these terms medical audit in France has been dealt with only sporadically, through individual initiatives and the action of isolated groups, whose results are more often than not published in lesser scientific reviews and whose dissemination is limited to health professionals.

Therefore the scientific literature in the French language has produced in the past 15 years rare articles or basic reports concerning the medical evaluation of health care acts $^{3-8}$ and a few publications relating the firsthand experience of a few isolated teams. ${ }^{9-13}$ A few consensus lectures have been delivered, in no planned order, most of which have raised criticisms of methodology without being communicated to the health professionals directly concerned. ${ }^{6}$

This weakness in the production of medical audits in France goes hand in hand with the absence of any structured health policy on audit. Various official texts from the Ministry of Health concerning the establishment of regulatory practice for health care acts have either not been applied or received only transitory follow up.

And yet the need to set up such a policy is self evident: the health care system in France is one of the most costly in the 20 OECD (Organisation for Economic Cooperation and Development) countries ( $£ 4$ bn in 1990 - that is, $£ 950$ per person) while it is far from being the most efficient as shown, for example, by its ranking among OECD countries for some performance indicators (box). Health care cover by the Assurance Maladie, which has regularly dwindled in the past 10 years $(80 \%$ in $1980,74 \%$ in 1990$)$, is one of the lowest in Europe. There is also an ever increasing socioprofessional health divide. It is as if those social groups having at their disposal a large sociocultural capital are able to appropriate much more quickly than other groups the means, through technical progress, of increasing their health capital.

This gap between the high cost of the health care 
system in France and its level of performance may be attributed to its socioeconomic organisation and to several factors which together increase the offer of care.

Doctors in France practise either in the private sector (107000 doctors paid on a consultational basis and representing almost all the outpatient care and a third of hospital care) or in the public sector $(63000$ salaried doctors). Outpatient care is assured by general practitioners $(58000)$ and specialists $(49000)$ who set up their practice wherever they choose. Patients have a permanent free choice of doctor and consult one or several general practitioners or specialists, as they wish. There is total freedom to consult any specialist. Patients pay for the medical care they receive (France and Belgium are the only two countries in the European Community where direct payment by insurers does not exist for outpatient care). Fees are set by a convention between the financial representatives of the national health service (Caisses Nationales d'Assurance Maladie) and the medical unions. There is a single standard fee that certain doctors, particularly specialists, have the right to exceed with "tact and restraint," but nobody has ever been able to define this concept. The elasticity has allowed a few to double or triple the flat rate, three quarters of which the Caisses d'Assurance Maladie reimburse. Many patients subscribe to additional insurance policies or to a mutual fund, which in part covers the expenditure not reimbursed by the national service. Hospital patients assume $20 \%$ of fees, apart from a daily cover charge, except in certain circumstances (maternity; patients with chronic illnesses or having relatively important surgical interventions). Finally, $7 \%$ of patients are fully covered by the national fund for all outpatient and hospital care. Three quarters of this last group of patients have a chronic illness, particularly cardiovascular, metabolic, respiratory, psychiatric conditions and tumours.

Five factors in this health care system explain the surge in health expenditure without any increase in medical or social efficacy.

Excessive growth of medical demography-At present 170000 doctors (one doctor per 300 inhabitants) practise in France. Their numbers have increased by $43 \%$ in 10 years, among general practitioners (by $19 \cdot 5 \%$ ) and particularly specialists (by $66 \%$ ), yet there is a strict correlation between the number of medical consultations per inhabitant and the number of specialists. By the year 2010 the number of doctors will have reached 210000 unless indispensable measures are taken to attenuate this dangerous spiral.

Excessive use of diagnostic procedures-Medical decision making does not sufficiently take into account the usefulness of diagnostic procedures for each patient. This is especially so for systematic radiological and biological investigations, which in over $80 \%$ of patients are useless, and whose excessive prescription explains the increase in the volume of tests performed by the private analytical laboratories.

Inappropriate use of high cost technical innovationsThese are either used even before they have been evaluated (computed tomography bone scan, prostatic

\section{Ranking of French health care system among OECD countries}

Child mortality

Male life expectancy at birth

Female life expectancy at birth

Mortality from infectious disease

Mortality from tumours

Mortality from trauma

(OECD data 1987)

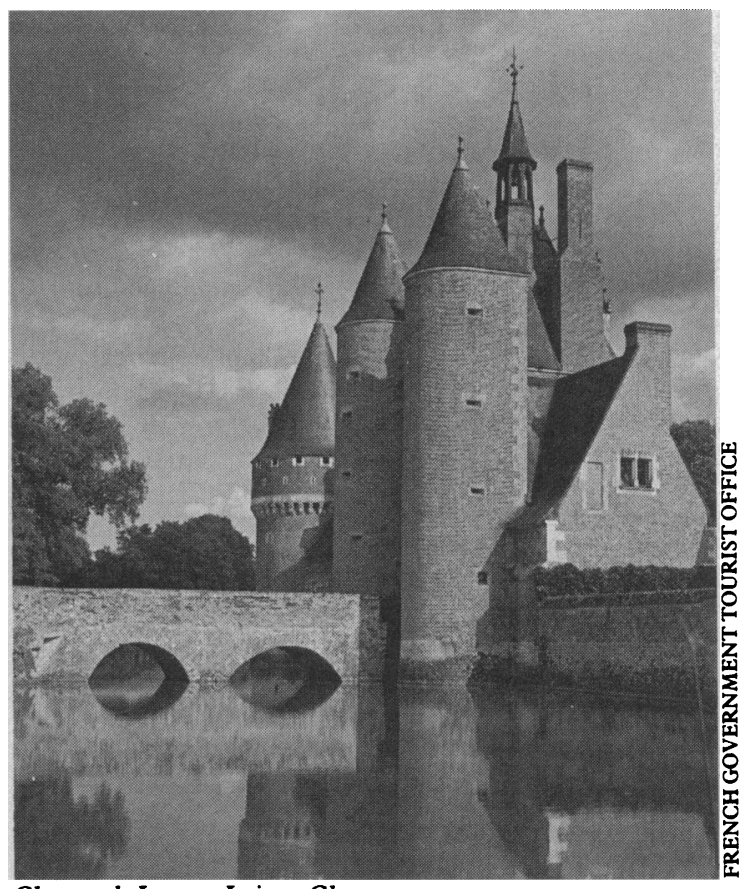

Chateau de Lassay, Loire et Cher

hyperthermia) or are hijacked from their legitimate indications $(75 \%$ of prescriptions for statins, a new therapeutic class of drugs for treating hyperlipidaemia, do not comply with their scientific indications).

Excessive consumption of pharmaceutical productsThe consumption of such products is the highest per head in the world, annually increasing at about $10 \%$. Despite the relatively low cost of drugs in France pharmaceutical expenditure in 1990 was $£ 9.6 \mathrm{bn}$ - that is, $£ 170$ per head.

Weight of investment in the private hospital sectorFinancial investment has facilitated the development of private hospitals (increased by $9.7 \%$ in 1990) and their specialisation to be able to perform an increasing number of high yield major surgical interventions (particularly orthopaedic and cardiovascular surgery).

Until 1984 there was no form of health care regulation in France. The Assurance Maladie fund was financed by social contributions from the various contributors insured: the chronic deficit between expenditure, which regularly increased, and assets was offset by a rise in social contributions. That period is now over: the amount of contributions at source according to the gross domestic product has now reached an intolerable level $(44 \cdot 8 \%$ versus $38 \cdot 8 \%$ on average for the OECD countries; $40.6 \%$ on average for the European Community; and $37.5 \%$ in Great Britain). A faltering economic growth rate is now weighing on the equilibrium of the system, owing to a lesser growth in assets, while growth in expenditure has remained high (increasing by $7 \cdot 5 \%$ on average per year in the past five years).

Since 1984 a global budget has been allocated region by region to public hospitals. This has partly made it possible to control expenditure in this sector but has not avoided its soaring increase elsewhere in medical equipment, admissions to private hospitals, and outpatient care. For this reason the government is negotiating with the medical unions to try to establish a form of budgetary regulation by offering the various health professionals an annual sum to cover fees. This external form of regulation, which economically is indispensable, must be associated absolutely with an internal form of regulation ${ }^{2}$ to ensure that health expenditure limitations do not have an adverse effect on the quality of care. This is why the various health care policy makers in France, particularly the financial department of the Assurance Maladie (CNAMTS), 
have now decided to go ahead with a quality assurance programme, aiming at guaranteeing social contributors with optimal quality for a given budget.

The Ministry of Health has therefore requested a panel of experts to make proposals with a view to developing medical evaluation of health care in France. Its report, published in $1989,{ }^{14}$ mainly resulted in the creation of the National Agency for the Development of Medical Evaluation (ANDEM), which aims at favouring the development of technological evaluation studies and medical audits in both the private and hospital sectors. It also seeks to contribute to establishing professional guidelines and disseminating them among all doctors practising in France. Since the agency was created last year guidelines have been established concerning both methodological aspects (consensus meetings) and various forms of professional practice in preventive medicine (for example, the prevention of post-transfusional hepatitis) and in curative medicine. Studies evaluating professional practice have also been performed throughout France in both public and private centres.

Everything therefore points to the development of medical audit becoming a reality in France. However, this cannot come about unless a certain number of conditions are respected: ( $a$ ) Clearly defining the objectives and insisting that the finality of any audit is first and foremost medical rather than economic; $(b)$ establishing a reliable information gathering system, in structural and financial terms, to dispose of data for use in the development of medical audits throughout France; $(c)$ developing professional or institutional encouragement, or both, for those who implement medical health care evaluation; $(d)$ training health professionals in medical audit, both in the framework of their initial studies and in further education; and $(e)$ offering quality information on health care evaluation to the population at large. There must be complete openness regarding evaluation to enable each member of French society to feel involved.

Medical audit is therefore taking on real shape in France, but many years will be needed for it to be developed nationally, to the point where it may fully play its part in regulating the health care system.

1 Beraud C, Amouretti M. Evaluer les activités hospitalières: une impérieuse nécessité. Fournal Economie Médicale 1989;7:147-60.

McKee M. Medical audit: a review. $\mathcal{F} R$ Soc Med 1989;82:474-7

3 Amouretti $M$, Salamon R. L'évaluation médicalisée des actions de soins: un enjeu pour les professionnels de santé. Gastroenterol Clin Biol 1991;15: $297-300$

4 Cabanis JN. La qualité du service à l'épreuve des réformes hospitalières. Techniques Hospitalières 1985;472:55-9.

Fessler JM, Bandelier R. Demain l'audit hospitalier. Gestions Hospitalières $1986 ; 252: 21$.

6 Giraud A, Jolly D. Le consensus en médecine: analyse et bilan des conférences de consensus dans le monde. Paris: Doin-Assistance Publique des Hôpitaux de Paris, 1991

7 Lombrail P, Brodin M, Gottot S, Lang J, Spector M, Naiditch M. L'audit médical à l'hôpiral Gestions Hospizalières 1987;269:507-10.

8 Melliere D. L'audit médical. Incidence sur les résulats médicaux, les coûts, formation des médecins. Nouv Presse Med 1980;9:339-42.

9 Acar J, Armengaud M, Drucker J, Humbert G, Manuel C, Vachon F. Antibiotic audit. Nouv Presse Med 1980;9:405-10.

10 Jolly D, Brodin M, Stephan JC. Les audits hospitaliers. L'hôpital à Paris 1982;68:102-4

1 Lé Gall JR, Loirat P, eds. Evaluation en réanimation. Paris: Masson, 1990

12 Raymond JM, Labadie JC, Fayon E, Buy F, Baldit C, Dumas, F, et al. Evaluation des procédures de décontamination utilisées dans les centres d'endoscopie digestive de Gironde. Gastroenterol Clin Biol 1990;14:134-9.

13 Raymond JM, Tissot B, Dartigues JF, Dumas F, Schouler L, Couzigou P, et al. Evaluation des facteurs influençant la qualité technique des coloscopies -enquête sur la région Aquitaine [abstract]. Gastroenterol Clin Biol 1991; 15:A18

14 Armogathe JF. Pour le développement de l'évaluation médicale. Paris: La Documentation Française, 1989.

\section{Audit Views}

$\mathrm{A}$ interesting proposal for an audit of maternity services is presented in the British Fournal of Obstetrics and Gynaecology 1991;98:1073-8. Based on the current computerised St Mary's information system, which covers all 15 maternity units in the North West Thames region, the outcome of pregnancy in "standard" primiparous women would be used as the basis for comparison of outcomes in units with different obstetric populations. A small group of clinicians, patients, and managers at the region would then prepare profiles for each unit, in which a similar group would be asked to respond with a development programme for the coming year. The audit cycle would be completed by monitoring the outcome.

A telephone survey of nebuliser use in 74 children's wards in England (Archives of Diseases in Childhood $1991 ; 66: 1351-3)$ found that drug delivery units were sometimes reused, though this is not recommended, and that only a third of wards carried out twice yearly servicing. Policy guidelines were available in fewer than half the district health authorities. Given the expense of nebulisers and their increasing use in the home, nationally agreed written instructions are urgently needed.

A cording to a review in the fournal of the American Medical Association (1991;266:2856-60), the use of practice guidelines in some parts of the United States has not only improved quality of care but led to a reduction in malpractice claims and in premiums paid by doctors. But difficulties in agreeing guidelines should not be underestimated, and where they have been disseminated they have sometimes had a negligible impact on clinical practice.

$\mathrm{B}$ ck pain is a common reason for referring patients to hospital. An analysis of 182 patients from 20 Oxford practices (British Fournal of General Practice 1991; 41:450-3) showed that consultations for backache had declined dramatically when the patients were reviewed five years later Most had had symptoms for at least six months before referral, but whereas general practitioners had expected advice and reassurance to be given for $72 \%$ of patients, two thirds of the referred patients actually received treatment in the outpatient clinic. Duplication of tests and physiotherapy was common. Spontaneous recovery is usual, and better patient information and agreed protocols for referral could lead to considerable savings in hospital costs.

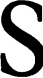
xty five patients in Wolverhampton who had undergone laryngectomy were sent questionnaires about their perceived disability and quality of life (Fournal of Laryngology and Otology 1991;105:934-8). Although half of them achieved a satisfactory oesophageal voice, $64 \%$ found the loss of voice a severe disability. And when the prevalence of nasal problems; difficulties with swallowing, micturition, defecation, and lifting; crusting of the stoma; and chest infections were considered it is surprising that $91 \%$ thought that the operation had been worth while. Perhaps they wanted to please the doctors.

A attempt to predict why new patients failed to attend neurological clinics in Belfast was made by studying information in the referral letter (Fournal of the Royal Society of Medicine 1991;84:662-3). Non-attenders represented $23 \%$ of appointments at the regional unit; important features were men aged under 50, symptoms for less than a year, referrals from accident and emergency departments, and waiting times of over two months. Tackling the last two items might reduce the number of defaulters.

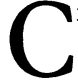

riteria for managing women with abnormal cervical smears should be based on available data comprising relative risk and life tables for survival according to different histological findings (British Fournal of Obstetrics and Gynaecology 1991;98:1069-72). In addition, women should be given repeated, anonymous questionnaires about the quality of management; streaming waiting times for appointments and providing written explanatory information help to minimise anxiety. 